\title{
Armeniens "sammetsrevolution" 2018 och varför den dröjde så länge
}

\author{
Vahagn Avedian ${ }^{\star}$ \\ $\mathrm{PhD}$, Historiske institutionen, Lunds universitet
}

\begin{abstract}
Armenia's Velvet Revolution - Why So Overdue?
In early April 2018 Armenia completed the transition from semi-presidential rule to a parliamentary republic. Under the slogan 'More power to the people', the ruling Republican Party had paved the way for the incumbent president, Serzh Sargsyan, to continue in power, now as prime minister as his second and final term of presidency was drawing to an end. However, the ensuing events ended with popular protests, the 'Velvet Revolution', which forced Sargsyan and the Republicans out of office. The new administration, led by the former opposition leader Nikol Pashinyan, has ousted several influential leaders and initiated an ambitious anti-corruption programme. Nonetheless, one significant issue remains: early elections that are supposed not only to reflect the prevailing political landscape in Armenia but also reform the country's election laws. What triggered the spring 2018 uprising, when corruption and social discontent have been both well-known and prevalent in Armenia over the past two decades? This article offers insights into the background to the popular uprising, and the relation between Armenia and its large and influential diaspora, citing two main factors for the delay since independence in 1991 - the historical legacy of the perils of internal disunity, together with the effects of the unresolved Karabakh conflict. It concludes with some reflections on the way forward.
\end{abstract}

Keywords: Armenia, diaspora, Caucasus, democracy, elections

För Armenien och armenier var 2018 ett händelserikt år fullspäckat av historiska jubileer och andra högtidlighållanden. Bland annat firades den 18 maj 100-årsminnet av den första republikens grundande 1918 och sedan den 21 september den nuvarande republikens återvunna självständighet från Sovjetunionen. Under hösten fyllde även huvudstaden Jerevans 2800 år och som vanligt högtidlighölls det armeniska folkmordets årsdag den 24 april. April månad 2018 utmärktes dessutom av Armeniens övergång från presidentstyre till parlamentarisk republik, något som utvecklades till att bli en världshändelse. Den allmänna förväntningen var att det styrande Republikanska Partiet (RPA) skulle behålla greppet om makten och att dess partiledare, den nu avgående presidenten Serzh Sargsyan, skulle fortsätta att leda landet som premiärminister med omfattande befogenheter.

\footnotetext{
^Kontaktinformasjon:Vahagn Avedian, epost: vahagn.avedian@armenica.org 
Den faktiska händelseutvecklingen innebar i stället att april 2018 kommer att gå till historien för den folkliga och framförallt fredliga revolution som ägde rum i Armenien och som dessutom var en stor överraskning för många, både inom och utanför landet. Det nya ledarskapet har sjösatt en rad olika reformarbeten för att bekämpa korruption och stärka demokratin i landet. Utvecklingen pågår i skrivande stund och utgången av "revolutionen» är således fortfarande oviss. Högst på listan stod ett tidigarelagt parlamentsval för att både bekräfta maktskiftet och reformera landets demokratiska grundstenar. Denna process har, som förväntat, inte varit utan problem. Den har mött hårt motstånd från RPA och dessutom påverkats av den geopolitiska situationen i Kaukasus och den sköra balansgång Armenien alltid tvingas till i sina relationer med den stora grannen i norr, Ryssland.

Den fråga som många ställde sig och som kommer att behöva betydande forskning för att på ett uttömmande sätt svara på är varför det dröjde nästan tre decennier sedan självständigheten innan armenierna tog ställning emot korruptionen och maktmissbruk i Armenien? Folk har alltid uttryckt sitt missnöje med dessa problem, men med undantag för några enskilda och kortlivade tillfällen har man aldrig utmanat regimen på det sätt som man gjorde i april 2018. Denna artikel ska erbjuda insikt i två bidragande faktorer i denna mångfacetterade process: ett historiskt perspektiv och en högst närvarande och inflytelserikt historiemedvetande samt hur den olösta Karabach-konflikten och omvärldens förhållningssätt i denna fråga har bidragit till utvecklingen i Armenien. Artikeln kommer först redogöra för dessa två aspekter innan det aktuella läget i Armenien presenteras, inklusive en kortfattad redovisning av de eventuella framtida vägar som detta kan leda till.

En sak bör påpekas inledningsvis, nämligen det magra forskningsutbud som finns tillgängligt när det gäller fallet Armenien. Precis som Carnegieanalytikern Thomas de Waal påpekat är Armenien ett svårtolkat land. Det har endast tre miljoner invånare och är ett relativt litet (den minsta av de före detta sovjetrepublikerna), men är ändå relativt välrepresenterat internationellt tack vare sin stora diaspora (uppskattad till närmare sju miljoner). Samtidigt som landet har nära relationer med Ryssland så har det även starka band till USA genom lobbygrupper i kongressen, och har dessutom liknande representation i Europa. Trots att Armenien är övervägande kristet, har landet goda relationer med Iran (de Waal 2018). Dessa faktorer gör att det är svårt att placera Armenien i någon specifik kategori, vilket delvis har bidragit till att det finns få akademiska verk om Armeniens utrikespolitik (Mirzoyan 2010: 4-5).

Det har skrivits ännu mindre om landets inrikespolitik och endast en liten del av det som publicerats är på engelska (och således tillgängligt för forskarvärlden utanför Armeniens gränser). Det enda undantaget i sammanhanget är just de allmänna valen och deras relation till det politiska läget vilka har uppmärksammats mestadels i form av analyser i massmedia, utvärderingar gjorda av OSSE eller organisationer med liknande bevakningsuppdrag. Detta kan också bekräftas av min egen observation från de workshop och seminarier (med deltagare från Norden) som jag 
har blivit inbjuden till där den samlade expertisen sysslar nästan uteslutande med studier rörande Georgien och Azerbajdzjan men knappast Armenien. På grund av forskningsläget är en överväldigande majoritet av de källor som används i denna artikeln just tidningsartiklar, rapporter från tankesmedjor och dylikt. Det bör även noteras att just med tanke på den beskrivna säregenheten hos Armenien och sättet man nu har valt att agera bör förhoppningsvis ändra på intresset att studera landet i större utsträckning än det man har gjort hittills.

\section{Armeniens färglösa revolution: "Sammetsrevolutionen»}

Den folkliga revolutionen startade med att Armenien i början av april övergick från att vara semipresidentstyrt till helparlamentarisk republik. Den reella makten flyttades från presidenten till premiärministern såtillvida att presidenten, som numera inte längre väljs av folket utan av parlamentet, får en mer eller mindre ceremoniell roll medan premiärministern, som också väljs av parlamentet, har den exekutiva makten. Dessutom utser parlamentet chefsåklagare, domare till högsta domstolen, ombudsmän med flera (National Assembly 2015). I korthet innebar alltså denna utveckling, åtminstone på pappret, mer makt åt folket eftersom parlamentet, som väljs av folket, nu enligt lagen kontrollerar det mesta. Detta var också den slogan som användes av det styrande RPA när grundlagsändringen som banade väg för maktöverlämningen från president till premiärminister initierades under 2015. Redan då höjdes röster om att detta utspel bara var ett försök från den sittande presidenten Serzh Sargsyans sida att klamra sig vid makten när hans andra (och enligt konstitutionen sista) mandatperiod slutade i början av april 2018. Oppositionen varnade för att det handlade om en strävan att etablera en "partistat» (News.am 2015). Folkomröstningen om grundlagsändringen kritiserades hårt för förekomsten av valfusk och hot. Det faktum att endast 50,8 procent av de röstberättigade deltog (av vilka drygt 66 procent röstade för grundlagsändringarna) tolkades av analytiker och kritiker som indikation på folkets ointresse och ett tecken på att medborgarna ansåg att ändringarna skulle gynna regeringen snarare än befolkningen (se t.ex. BBC 2015).

Sargsyan försökte slå ifrån sig kritiken genom att försäkra att han inte skulle kandidera till premiärminister när hans presidentämbete avslutades men många tvivlade på detta löfte. ${ }^{1}$ Det visade sig att de hade fog för sin misstänksamhet när RPA den 7 april 2018 nominerade just Sargsyan till landets nye premiärminister (Tert.am 2018). Nomineringen bekräftades enkelt genom en omröstning i parlamentet den 17 april eftersom RPA vid den tidpunkten kontrollerade 58 (inklusive stödröster och alliansröster) av parlamentets 105 platser (Arka Nerws Agency 2018b). Konsekvenserna av nomineringen blev betydligt annorlunda än vad partiet troligtvis föreställt sig. Inom loppet av en knapp vecka tvingades Sargsyan den 23 april att avgå som ett resultat av

\footnotetext{
${ }^{1}$ För en analys av det senaste parlamentsvalet i Armenien (2 april 2017) som i princip banade väg för det tilltänkta maktövertagandet se Avedian (2017).
} 
det som kommit att kallas för "Sammetsrevolutionen» (The Guardian 2018). Enligt gällande regler skulle vicepremiärminister Karen Karapetyan (RPA) utses till tillförordnad premiärminister fram till dess att extrainsatt val kunde hållas. Förslaget avvisades dock av oppositionsledaren Nikol Pashinyan som framhöll att man inte litade på att ett val under rådande omständigheter skulle gå rättvist till, främst på grund av befintliga valregler men också med anledning av förekomsten av utbrett fusk vid tidigare val.

Pashinyan krävde att RPA skulle lämna ifrån sig makten och han nomineras till premiärministerposten som "folkets kandidat». Karapetyan kontrade med att fråga "Vad innebär 'folkets kandidat'? Jag vet inte något land där premiärministern väljs på detta sätt. Det finns val för sådant. Om han är folkets val innebär det att de kommer att välja honom» (Antidze \& Mkrtchyan 2018). När Pashinyan vägrade kompromissa och demonstrationerna fortsatte att växa valde RPA att ge vika och gå med på hans kandidatur. Det krävdes dock två röstningsomgångar i parlamentet för att han skulle bli vald. I första omgången fick han endast 47 av de 53 röster som krävdes (av totalt 105) eftersom RPA fortfarande var i majoritet (BBC 2018).

Om även den andra omgången misslyckades skulle landet enligt konstitutionen tvingas till nyval. Nu utvidgades protesterna och Pashinyan hotade med generalstrejk och civil olydnad genom att blockera gator och regeringsbyggnader. Situationen för RPA försämrades ännu mer när koalitionspartnern, Armeniska Revolutionära Federationen (ARF), valde att lämna regeringen och anslöt sig till oppositionen. Efter detta meddelade RPA att de, för att bryta dödläget, skulle se till att Pashinyan fick tillräckligt med röster i den andra omgången och därmed undvika nyval. Många menade att Republikanernas tvärvändning var ett strategiskt drag för att avvärja ett potentiellt katastrofval med tanke på de rådande omständigheterna och den allmänna opinionen. Det spekulerades även om att eliten inom RPA, som suttit vid makten sedan 1999, antog att Pashinyans administration skulle självdö inom kort när folkets uppskruvade förväntningar inte kunde infrias. Enligt detta rykte valde de därför att släppa fram honom för att själva kunna omgruppera och återkomma med nya krafter när protesterna hade lagt sig och folket insett att Pashinyans löften var populistiska snarare än realistiska.

Pashinyan valdes till premiärminister den 8 maj 2018 (Reuters 2018a). Frågan är hur detta kunde hända i Armenien där det politiska läget, trots utbrett socialt missnöje, länge varit relativt stabilt och RPA verkat ha ett stadigt grepp om den politiska makten. Och, varför det var just vid den här tidpunkten som folket till slut fick nog av korruption och oligarkiskt styre?

\section{„Dansade Armenien nyss sin väg till revolution?»}

Efter att Pashinyan valts till premiärminister kunde konstateras att det som för många föreföll näst intill otänkbart faktiskt hade inträffat i Armenien. Befolkningen hade inte bara avhyst en oligarkisk och korruptionstyngd administration utan det hela hade dessutom gått helt fredligt till. Till och med omvärlden verkade påtagligt 
överraskad, något som framgick bland andra av frågan hos artikelförfattaren i Washington Post som undrade "Dansade Armenien nyss sin väg till revolution?" (Ferris-Rotman 2018). Många trodde att protesterna, som så många gånger tidigare sedan självständigheten 1991, skulle få ett begränsat antal deltagare och avta inom en vecka eller två. Men denna gång var det tiotusentals, om inte hundratusentals, som anslöt sig till demonstrationerna och vägrade ge vika innan deras krav hörsammats. Det som inte åstadkommits genom allmänna val lyckades nu genom protester som återgavs $\mathrm{i}$ världspressen och visade folk som i mängder dansande på gatorna $\mathrm{i}$ Jerevan. Mest överraskade var nog armenierna själva, både i och utanför Armenien, som plötsligt tycktes ha insett att det var möjligt att åstadkomma en förändring bara tillräckligt många höjde sin röst och löpte linan ut. Det hela kan liknas vid en uppenbarelse som var över två decennier försenad, men självklart är detta en förenklad bild. Som i många liknande fall var det kombination av olika faktorer som gjorde att omständigheterna var de rätta för den här typen av förändring. Det faktum att det gick relativt fredligt till, utan blodiga sammandrabbningar eller ens massarresteringar som tyvärr brukar höra till vanligheten i dessa sammanhang, var kanske det som överraskade mest.

Det som inträffade var summan av nästan tre decenniers politiska, ekonomiska och sociala faktorer och processer. Den allmänna attityden bland folket, något som psykologiforskaren Sona Manusyan har studerat, är en viktig och avgörande pusselbit som inte bör underskattas. Genom intervjuer och andra undersökningar har Manusyan analyserat varför armenierna inte har lyckats mobilisera sig tidigare utan istället till synes nöjt sig med att klaga över situationen (Ishkanian 2017b). Hon har granskat detta ur ett kulturellt och nationellt identitetsperspektiv och bland annat frågat sig hur det kommer sig att »det finns en strävan att förändra situationen parallellt med rädslan för förändring?». Hennes forskning konstaterar att det finns "ett motstånd mot motståndet” (citerad i Ishkanian 2017b: 12). I relation till detta föreslår jag nedan två element som särskilt tongivande i detta hänseende, nämligen ett tusenårigt historiemedvetande och historiebruk samt effekten från en nutida pågående konflikt och omvärldens förhållningssätt i frågan. Sedan återgår jag till "folkets val» och det tilltänkta tidigarelagda parlamentsval som mycket väl kan vara ett av de viktigaste valen som hållits i Armeniens moderna historia.

\section{Två decennier av korruption och oligarki}

Även om många verkade överraskade av händelseutvecklingen så kom revolutionen inte plötsligt. Det var snarare så att ett missnöje som jäst under många år, under tre olika administrationers ledning, till sist mynnade ut i att folket förlorade förtroendet för det demokratiska systemet och möjligheten att åstadkomma förändring genom att utöva sina rättigheter, det vill säga genom avyttrandet av sin röst i rättvisa val.

Armeniens styrelseskick har sedan självständigheten 1991 i jämförelse med Kaukasusgrannarna Georgien och Azerbajdzjan betraktats som ett slags mellanting. 
Medan Georgien porträtterats som det land som valt en mer konfrontationsenlig bana med sin "Rosenrevolution» och kommit längst i demokratiseringen av landet så har Azerbajdzjan präglats av maktkamper som relativt tidigt, i oktober 1993, resulterade i konsolideringen av makten hos Alijevfamiljen och ett utpräglat auktoritärt styre (se t.ex. Welt 2012). Armenien valde tillsynes en mellanväg, en sorts kvasidemokrati som tagit små steg i rätt riktning, även om det ibland inneburit ett steg framåt och två bakåt. Denna beskrivning passar inte bara in på Armenien; flera av de postsovjetiska republikerna har präglats av ett liknande oligarkiskt styre. ${ }^{2}$ Framtiden för landet framstod strax efter självständigheten 1991 som lovande. Armenien beskrevs till och med som en "'ö av demokratiska reformer' bland tidigare sovjetiska republiker» (Defeis 1998: 60). Men, ända sedan dess har landet kämpat mot en utbredd korruption som effektivt bidragit till att bromsa både landets politiska och ekonomiska utveckling. Oligarkin och korruptionen var dock endast en del av problemet. En annan viktig bidragande faktor till situationen i Armenien har varit den ännu olösta och högst aktiva (trots att den ofta felaktigt kallas för "frusen») konflikten med Azerbajdzjan över enklaven Nagorno-Karabach. ${ }^{3}$

Konflikten har inneburit att Azerbajdzjan, tillsammans med Turkiet, har upprätthållit ett totalt embargo mot Armenien genom stängda gränser så väl som utfrysning av Armenien från regionala projekt och samarbeten. Bakus politik har gått under ledstjärnan: "välstånd utan Karabach eller fattigdom med Karabach» (Mammadov 2011). Ambitionen har varit att driva Armenien in i en sådan fattigdom att "folket till och med slutar tänka på Karabach» (Ibrahim 2011; se även Alijev 2011). Konfilkten har även en annan inverkan på parternas politiska utveckling. I båda länderna har kunskapen om hur politiskt tumult och instabilitet på hemmaplan kan utnyttjas av motståndaren använts för att hålla oppositionen i schack. I Azerbajdzjan bidrog interna maktkamper mellan 1992 och 1993, mitt under det rasande Karabach-kriget, onekligen till armeniernas framgångar i striderna. ${ }^{4}$ Armeniernas erfarenheter i detta hänseende går dock betydligt längre tillbaka i tiden.

\section{En tusenårig historieläxa som fortfarande är vid liv}

Armenierna är högst medvetna om hur maktkamper försvagade Azerbajdzjan genom att ta ledarnas fokus från fronten i Karabach och fick ödesdigra konsekvenser. Förutom denna nutida läxa så finns det en inneboende historielektion hos armenierna som har hållit oppositionen och allmänhetens kritik i styr, nämligen valet mellan

\footnotetext{
${ }^{2}$ Snarare ett plutokratiskt styre där flera ministrar och parlamentsledamöter, i brott mot landets konstitution, innehar stora affärsintressen eller har monopol på införsel eller produktion av olika varor och tjänster i landet.

${ }^{3}$ För mer information om konflikten om Nagorno-Karabach besök karabach.se.

${ }^{4}$ Under denna period avsattes fyra azerbajdzjanska presidenter under kuppartade förhållanden: Ayaz Mutallibov, mars 1992; Yagub Mammadov, maj 1992; Ayaz Mutallibov, maj 1992 och slutligen Abulfaz Elchibey, september 1993 som ersattes av Hejdar Alijev i oktober 1993.
} 
"vårt eget sjuka lamm och fiendens friska varg». Detta edikt går tillbaka till 400-talet och den siste armeniske kungen i arsacidiska (Artashesian) dynastin, Artashes IV. Missnöjda med den unge och relativt inkompetente kungen vände sig de armeniska furstarna till katolikos (ärkebiskop) Sahak Partev för att få hans samtycke att bjuda in den persiske kungen att överta makten i Armenien. Partev svar lär ha varit "hellre ens eget sjuka lamm, än fiendens friska varg». Han talade för döva öron. Furstarna ignorerade hans varning och gick vidare med sitt beslut. Detta innebar slutet för Arsaciddynastins trehundraåriga självstyre då Armenien kom att införlivas i Sasanidiska Persien som en provins under en persisk guvernör. Det skulle dröja nästan fyra sekler innan Armenien på 800-talet kunde återfå sin självständighet. Furstarnas misstag blev en dyrbar historisk läxa för armenierna som ekat genom olika tidsepoker ända fram till idag.

När jag för första gången besökte Armenien 1995 fick jag på egen hand uppleva hur aktuell denna historielektion var. ${ }^{5}$ Den återvunna självständigheten var endast fyra år gammal och det hade gått ett år sedan vapenstilleståndet i Karabachkonflikten trätt i kraft. Både Georgien och Azerbajdzjan hade genomgått blodiga statskupper med inbördeskrig till följd. Armenien däremot var politiskt sett förhållandevis stabilt. Folket var missnöjda med att president Levon Ter-Petrosyans administration inte kunnat infria sina vallöften om ekonomiskt tillväxt, ökade arbetstillfällen och en permanent lösning på Karabachkonflikten. Redan då var korruptionen ett faktum och utpekades som orsaken till det mesta som var fel. Pengar som skickades hem från den välbärgade armeniska diasporan verkade försvinna i ett bottenlöst slukhål. Trots det tycktes det finnas en allmän konsensus om att "jo, vi vet att de stjäl; men pengarna går inte långt utan hamnar i armeniska fickor». Att uthärda korrupta politiker, tillika tjuvar, ansågs vara att föredra framför att göra något som kunde orsaka instabilitet och eventuellt riskera att man kastades in i ett inbördeskrig. Grannländerna tjänade i detta hänseende som avskräckande exempel, speciellt Azerbajdzjan där statskupperna, som tidigare nämnts, fått påtagliga konsekvenser för landets krigsförmåga i Karabachkonflikten. Detta, sa man, fick inte hända i Armenien. Vid den tidpunkten kändes detta ställningstagande inte bara logiskt utan även tämligen beundransvärt. Man valde nationens bästa i ett långtidsperspektiv framför att fokusera på individuella problem i nutid. Förhoppningen var att problemen skulle försvinna när alla hade roffat åt sig tillräckligt mycket för att bli mätta och var redo att ägna sig åt landets och kollektivets bästa.

Så blev det bevisligen inte eftersom åren gick utan att detta beteende upphörde. Korruptionen förlamade landet samtidigt som folket och oppositionen inte verkade kunna samla tillräckligt med kraft för att utmana de styrande på ett övertygande sätt. Vid nästan varje val observerades ett utbrett valfusk utan att det orsakade några större och ihållande protester. I de fall då någon insisterade på att kritisera den

\footnotetext{
${ }^{5}$ Dessa observationer är utifrån mina egna privata samtal med olika personer, både bosatta i Armenien och diasporaarmenier.
} 
styrande eliten höjdes snabbt andra röster som manade till försiktighet och framhöll att fienden (läs Turkiet och Azerbajdzjan) var redo att utnyttja en situation där Armenien försvagats inifrån genom protester. I praktiken innebar det tyst acceptans av det som var fel i Armenien. Detta var självklart inte det enda skälet till att oppositionen misslyckades att bilda en enad front, men likväl en viktig bidragande faktor, inte minst hos diasporan.

Med en nästintill utopisk bild av faderlandet som efter sju decennier hade återfått sin självständighet, var den armeniska diasporan ytterst mån om att försvara denna självständighet, hur bristfällig den än var. „Det må inte vara perfekt, men det är fortfarande vårt eget fria Armenien" var en vanlig kommentar i detta sammanhang. När Armeniska riksförbundet i Sverige i ett öppet brev fördömde dödsskjutningarna efter presidentvalet 2008 och krävde att regimen skulle respektera yttrandefriheten och andra demokratiska värderingar så bemöttes detta av massiv kritik från armeniska nationalister i Sverige (Armeniska riksförbundet i Sverige 2008; för dödskjutningarna se t.ex. $B B C$ 2008). Argumentationen var fortfarande densamma: vår sjuka armeniska demokrati bör försvaras så att ärkefienden Turkiet samt Azerbajdzjan inte ges tillfälle att utnyttja situationen. Särskilt bland diasporan var oron påtagligt för att Turkiet fortfarande väntade på tillfälle att avsluta det ofullbordade folkmordet under första världskriget.

Den armeniska diasporans unika ställning och dess inverkan på Armeniens ekonomiska och politiska utveckling är viktig i sammanhanget. Som Alla Mirzoyan påpekat utgör diasporan "ett viktigt europeiserings- och globaliseringsverktyg", en betydelsefull faktor som både Georgien och Azerbajdzjan saknar (Mirzoyan 2010: 162). Förutom att diasporan agerar som en länk till de västerländska demokratiinstitutionerna och injicerar Armeniens diplomati och politik med viktigt underlag i detta avseende, fyller den även en annan mer påtaglig ekonomisk funktion genom att skicka penningförsändelser hem till sina familjer i Armenien (sammanlagt beräknade till 17-24 procent av landets BNP (Se Grijalva 2017: 90). Denna hemskickade summa är dessutom inte enbart en viktig ekonomisk faktor utan berättigar även diasporan, om än implicit, till en relativt avgörande röst i utformningen av Armeniens politik, både på den inhemska arenan och, i synnerhet, på den internationella scenen, särskilt i frågor som berör det armeniska folkmordets erkännande och Karabach. Vidare spelar omvärlden, och speciellt stormakterna, en viktig roll i utvecklingen i Armenien. Också i detta fall är Karabachkonflikten något som bidragit till att externa aktörer direkt och indirekt på olika sätt påverkat Armeniens vägval.

\section{Karabachkonfliktens dubbla effekt: Policy om strikt neutralitet}

Omvärldens ställningstagande har spelat en viktig roll i den politiska utvecklingen i Armenien, främst genom det sätt på vilket man analyserat och bedömt utvecklingen i Armenien respektive Azerbajdzjan. De tre länderna i Kaukasusregionen, Armenien, Azerbajdzjan och Georgien, jämförs ofta med en sorts kollektiv måttstock på hur långt respektive land har utvecklats $\mathrm{i}$ en viss aspekt, särskilt när det 
gäller demokratisering. Så gott som varje val i Kaukasus har sedan Sovjetunionens fall övervakats av internationella delegationer från bland andra Organisationen för säkerhet och samarbete i Europa (OSSE) och Europarådets parlamentariska församling (PACE). Uttalanden från dessa organisationer om de olika valen har varit en viktig indikation på demokratins tillstånd och utveckling i de tre kaukasiska länderna. I Armeniens och Azerbajdzjans fall har emellertid dessa uttalanden låtit misstänkt likartade och dessutom varit återhållsamma i sin kritik. ${ }^{6}$ Likheten har varit slående i det avseende att observatörerna inte berömt det som förtiänat beröm och heller inte fördömt det som borde ha fördömts (Avedian 2013). Det tycks som att Europa, med medlarrollen i Karabachkonflikten $\mathrm{i}$ åtanke, inte velat gå ut för hårt $\mathrm{i}$ ett visst fall för att inte riskera att beskyllas för partiskhet. Den tama retoriken från framförallt EUs håll har missbrukats av regimerna i Armenien och Azerbajdzjan som använt avsaknaden av påtaglig kritik som bekräftelse på sin egen legitimitet. ${ }^{7}$

Europas policyval har också inneburit en missad möjlighet att "neutralisera» konflikten som ryskt maktmedel. Att Ryssland använder konflikten som påtryckning blev uppenbart 2013 då Armenien stod vid vägskälet mellan EU (i form av associationsavtalet DCFTA $)^{8}$ och den då icke-existerande Rysslandsledda Eurasiska ekonomiska unionen (EEU) (se Linde 2015). Få tvivlade över vad som hade fått Armeniens ledning att välja det senare trots att man under fyra års tid förhandlat med EU om ett avtal om djupare demokratiskt och ekonomiskt samarbete som skulle undertecknas under Vilniustoppmötet 28-29 november 2013. Efter två timmars möte den 3 september i Moskva mellan Sargsyan och Putin bakom stängda dörrar meddelade Armenien överraskande att man gjorde en tvärvändning och skulle välja EEU istället för associationsavtalet med EU. Även om det aldrig medgavs så misstänkte många att Armenien hade hotats med höjda naturgaspriser (liknande hot som Moskva hade framfört till Ukraina och Moldavien inför deras förhandlingar med EU) men framförallt också att Moskva meddelat hur ett fel val från Armeniens sida skulle kunna påverka den pågående Karabachkonflikten. Armenien hade minst sagt förnedrats av Ryssland i en tydlig maktdemonstration och markering gentemot EU (Avedian 2013).

Med undantag för en kortvarig protestvåg mot "storebror» Ryssland som hade förödmjukat Armenien internationellt så blev reaktionerna inte mer påtagliga än så. Denna likgiltighet var lika anmärkningsvärt internationellt då man helt enkelt tycktes acceptera det hela utan några större protester (se t.ex. Azatutyun 2013b), ${ }^{9}$

\footnotetext{
${ }^{6}$ Först under hösten 2015 kom entydig kritik från Europaparlamentet som uppmanade till riktade sanktioner mot vissa individer i Azerbajdzjan (Europeiska Parlamentet 2015).

${ }^{7}$ För Armenien se t.ex. Azatutyun (2013a). För Azerbajdzjans fall se t.ex. Gogia (2017).

${ }^{8}$ För det tilltänkta associationsavtalet (Deep and Comprehensive Free Trade Area, DCFTA) se European Commission (2013).

${ }^{9}$ Se t.ex. uttalande från Stefan Füle, EU:s Kommissionär med ansvar för utvidgning och grannskapspolitik, där han, trots protester mot Rysslands påtryckningar, menade att man wrespekterar Armeniens val» (Füle 2013). Även Carl Bildt, dåvarande svensk utrikesminister, var snabbt ute och deklarerade att erbjudandet om Armeniens EU-samarbete inte längre var aktuellt (Azatutyun 2013b).
} 
något som bör tillskrivas den rådande atmosfären i Armenien. Korruptionen spelade en central roll i att landet betraktades som en oattraktiv marknad för utländska investeringar, ekonomiska så väl som politiska. Även här spelar historien en viktig roll, i synnerhet erfarenheterna från första världskriget och det armeniska folkmordets kölvatten. De armeniska ledarnas övertro på västmakternas löften (främst löften från USA och Storbritannien men också från Frankrike) om skippande av rättvisa efter kriget visade sig vara ett ödesdigert misstag när man väntade på hjälp som aldrig kom. När västmakterna övergav kraven på bestraffning av de skyldiga för massakrerna under första världskriget samt etableringen av ett förenat Armenien (Sèvres-avtalet 1920) till förmån för bättre relationer med den nyetablerade turkiska republiken (Lausanne-avtalet 1923) såg många armenier Ryssland som den enda militära garanten för Armeniens existens (Mirzoyan 2010: 16). Detta var dock en sanning med modifikation då alliansen med Ryssland ansågs vara ett nödvändigt ont. 1920 offrade man sin självständighet genom att bli en sovjetrepublik, men bara för att erhålla ryskt beskydd mot den annalkande turkiska armén som skulle kunna orsaka den armeniska nationens totala förintelse.

Tilltron till västmakterna levde trots allt kvar bland armenierna, i synnerhet bland diasporan, något som återaktualiserades när Karabachkonflikten flammade upp i slutet av 1980-talet. Den nya politiska elit som växte fram i Armenien under slutet av denna period och småningom utropade självständighet från Sovjetunionen hade en radikalt förändrad syn på historien och historiebruket. Dessa ledare menade att den "naiva" tilltron till stormakterna bland armenierna samt den demoniserande bilden av Turkiet måste tonas ned. En sådan målsättning kunde märkas tydligt 1991 hos den första administrationen, lett av Levon Ter-Petrosyan, efter den återvunna självständigheten (Libaridian 1991: 3). Enligt Ter-Petorsyans administration hade historien bevisat att man oftast behöver pragmatiska och enkla beslut i nuet som utgår från rådande omständigheter (t.ex. att normaliseringen av relationerna med Turkiet nödvändiggjorde behovet att tona ner folkmordsfrågan), inte från komplexa historiska analyser (Mirzoyan 2010: 72). Till saken hör att Ter-Petrosyan och flera av hans närmaste medarbetare, inklusive hans nationella säkerhetsrådgivare Gerard Libaridian, var professionella historiker som nu blivit statsmän. Det är därför föga förvånande att erfarenheterna från första världskriget och folkmordet kom att spela en avgörande roll i formandet av Armeniens utrikespolitik, även om de själva tyckte att historiska relationer och tolkningar var en belastning snarare än en tillgång (Astourian 2005: 83-4; Libaridian 2004: 268). Till slut visade det sig dock att TerPetrosyan och hans medarbetare själva var naiva när de trodde att det var möjligt att bortse helt från historien till förmån för samtida pragmatiska behov.

Historien och dess erfarenheter fortsatte att åkallas, både i relation till balansgången mellan väst och Ryssland och när det gällde konfrontationen med makthavare i Armenien. Historien fortsatte att spela en viktig roll i kuvandet av oppositionen och tystandet av allmänhetens röster om maktmissbruk och 
korruption i landet. Men så hände det något under april 2018. Folket hade helt enkelt fått nog. Den dittills tillsynes rådande likgiltigheten gentemot korruption och valfusk visade sig vara ett olycksbådande tecken på stundande explosion. Istället för ett tyst medgivande till regimens felsteg skulle förtegenheten mycket väl bero på dold hjälplöshet och rådlöshet inför ett annalkande utbrott: den missnöjda skaran kokar ner till en kritisk massa när de som kan och har råd emigrerar; de som blir kvar är de som inte kan eller har råd att lämna landet samt de som stannar kvar av ideologiska och principiella skäl. Därmed var den folkliga resningen i april 2018 en tidsfråga.

\section{Droppen som fyllde bägaren: RPAs felkalkyl avseende folkets reaktion}

Måttet var rågat när RPA insisterande på att hålla Sargsyan kvar vid makten genom att utnyttja sin majoritet i parlamentet och välja honom till premiärminister. Omval brukar i "riktiga» demokratier innebära gott betyg från allmänheten och därför förnyat förtroende. I bristfälliga demokratier behöver däremot ett omval inte ha någon korrelation med framgång eller popularitet, utan är snarare en indikation på brister och vanstyre. Detta har varit fallet i Armenien och särskilt i samband med Sargsyans ämbetsperiod som präglades av ökad arbetslöshet, hög andel utvandring och utlandslån som fyrfaldigats sedan han valdes till president första gången 2008: från 13,52 procent (relationen utlandslån till BNP) till 58 procent, motsvarande 6,8 miljarder USD år 2017 (Berberian 2018). Droppen som fyllde bägaren var de styrandes naiva felkalkyl avseende folkets reaktion på Sargsyans fortsatta styre.

När Nikol Pashinyan utmanade det styrande RPA och valet av Serzh Sargsyan som landets premiärminister så vaknade en folklig rörelse som det politiska etablissemanget inte räknat med. Det missnöje som pyrt i nära tre decennier flammade nu upp och kunde inte släckas. Regimen förstod tidigt att ett eventuellt våldsamt ingripande, likt det efter presidentvalet 2008, sannolikt skulle urarta och att situationen skulle kunna utnyttjas av Baku för att lansera en bredare offensiv än den i början av april 2016 (se The Economist 2016). Mycket riktigt gjorde Karabachkonflikten sig snart påmind: redan ett par dagar efter att protesterna mot utnämningen av Sargsyan till premiärminister började, kom det rapporter om azeriska truppförstärkningar längs frontlinjen i Karabach (Asbarez 2018). Samtidigt förekom kommentarer och dementier på sociala medier om att den här typen av nyheter var fabricerade av den styrande regimen för att tygla protesterna. Likväl fanns den konstanta oron för konflikt och instabilitet där. Folk manade varandra till försiktighet och varnade för att om protesterna blev våldsamma skulle detta utnyttjas av ens "fiender». Några fler sammandrabbningar mellan armeniska och azeriska styrkor blev det dock inte och den folkliga rörelsen fick ha sin gång. 


\section{Val med dubbel innebörd: reform och bekräftelse av folkets seger}

Även om "folkets kandidat» segrade och Pashinyan bildade en bred koalitionsregering bestående av samtliga partier förutom RPA så återstod ett väsentligt hinder: RPA hade fortfarande (efter ett par avhopp samt upplösta allianser) ett robust maktinnehav i form av 50 av parlamentets 105 platser. Pashinyans koalition hade 47 platser medan åtta ledamöter numera var "oberoende». Den nya minoritetsregeringen behövde ett nyval för att kunna bekräfta sin legitimitet och auktoritet, något som alla inklusive RPA var överens om. Problemet var de gällande valreglerna som alla, förutom RPA, verkade vilja reformera innan nyval kunde hållas samt tidpunkten för valet.

Armenien hade sedan 1995 haft ett valsystem som gick ut på att parlamentsledamöter valdes in via två olika listor: 56 av 131 ledamöter (gamla systemet innan man bytte till dagens 105 platser) valdes in via proportionella listor där kandidater nominerades i olika valkretsar och den kandidat som fick flest röster i valkretsen valdes in till parlamentet. Övriga 75 ledamöter valdes in från nationella listor för respektive parti, via ett så kallat "majoritarian system» (National Assembly 1999). Själva valet gick till så att varje väljare lämnade in två valsedlar: en med den lokala kandidatens namn ikryssat och en andra valsedel för ett visst parti med deras egen rangordnade kandidatlista. Detta innebar att man i praktiken kunde välja en lokal kandidat från ett parti och rösta på ett annat parti på den nationella listan. Detta förändrades i och med grundlagsändringarna 2015 som banade väg för antagandet av nya valregler den 25 maj 2016. Då reducerades antal ledamöter från 131 till 101 (plus fyra för landets minoritetsgrupper: ryssar, assyrier, yezidier och kurder). Dessutom övergavs de två parallella valsedlarna och ersattes med en så kallad "öppen» valsedel per parti (ganska likt det svenska riksdagsvalet med personröster) (OSCE/ ODIHR 2016: 8). Nu röstade man genom att välja ett visst partis valsedel för sin egen valkrets och eventuellt även kryssa för en särskild kandidat på listan. Varje partis erhållna platser i parlamentet tillsattes sedan till hälften från partiets egen rangordnade lista medan den andra hälften utgjordes av de personkryssade kandidaterna.

Detta system kritiserades av alla partier förutom det regerande RPA som initierat grundlagsändringarna och drev igenom dem i parlamentet med stöd från ARF och "Välmående Armenien» (BHK) som vid tiden samarbetade med RPA. Kritikerna menade att systemet, speciellt i kombination med utbrett röstfiske där lokala oligarker och andra makthavare tillhörande RPA betalade invånare eller utövade press på dem, gynnade det styrande partiet genom att de på så vis kraftigt kunde öka sina ledamöters antal i parlamentet. ${ }^{10}$ Dessa anklagelser bekräftades bland annat av valobservatörer under det påföljande parlamentsvalet 2017 där man

\footnotetext{
${ }^{10}$ Under parlamentsvalet 2017 rapporterade flera källor hur representanter för både Republikanska Partiet och den största oppositionspartiet »Välmående Armenien» betalade 20000 -sedlar (cirka 350 SEK) tillsammans med sitt partis röstsedel till folk i röstlokalerna (se t.ex. Azatutyun 2017).
} 
rapporterade om trovärdiga bevis på köpta röster och påtryckningar på statsanställda att rösta på enskilda kandidater (PACE 2017). Dessutom maximerade man sina parlamentsplatser genom att värva lokala rika och inflytelserika kandidater som fick många personröster. Pashinyans administration insisterade därför på att valreglerna måste reformeras innan nyval hölls.

De nya ledarna tillsatte två oberoende kommissioner för att ta fram förslag till revideringar av existerande vallagar. ${ }^{11}$ Snart framkom att samtliga partier förutom RPA förespråkade ett system där man övergav "öppna» valsedlar (med personval) och istället införde "stängda» eller "fasta» listor (Hraparak 2018). Avsikten med revideringen var att åstadkomma rangordnade och slutgiltiga valsedlar där väljaren fokuserade på partiets ideologi och politiska program istället för på enskilda personer. Det skulle, åtminstone i teorin, minska individuella kandidaters inflytande i de egna lokala valkretsarna och därmed försvåra röstfiske och annat valfusk.

En annan viktig fråga som diskuterades var spärrgränsen till parlamentet. I det gällande systemet måste enskilda partier få minst fem procent av rösterna medan gränsen för allianser bestående av två eller flera partier låg på sju procent. Den regeringstillsatta kommissionen föreslog en sänkning av dessa gränser till fyra respektive sex procent, siffror som enligt uppgift var baserade på studier av världens "mest demokratiska» länder (Transparancy International 2018). I deras åsikt var en alltför hög spärrgräns, som till exempel den i Turkiet på tio procent, diskriminerande och konstruerad för att hålla oppositionen ute medan en alldeles för låg, eller inte någon spärr alls som i det nederländska systemet, istället öppnade för ett fragmentiserat parlamentet. Det senare kan i sin tur medföra att man sannolikt måste bilda en minoritets- eller en koalitionsregering som tenderar bli kortlivad eller får begränsat handlingsutrymme eftersom varje beslut innebär stora kompromisser.

Under tiden pågick en annan ytterst viktig process, nämligen val av borgmästare i Jerevan. Den tidigare borgmästaren, Taron Margaryan (RPA), avgick den 9 juli 2018 efter nästan sju år på posten, anklagad för korruption och för att ha berikat sig olagligt med hjälp av allmänna medel (Civilnet 2018). Valet av ny borgmästare var betydelsefullt av två skäl: för det första bor en tredjedel av landets befolkning i miljonstaden Jerevan vilket gör borgmästarposten till ett viktigt politiskt ämbete i Armenien. Än viktigare var det faktum att valet av många ansågs vara en fingervisning inför det kommande parlamentsvalet. RPA avstod intressant nog från att ens nominera en kandidat till borgmästarposten, något som tolkades som ett tecken på hur allvarligt läget var för partiet (Lragir 2018). RPA tycktes inte ville riskera ännu ett nederlag så tätt inpå förlusten av regeringsmakten, utan hellre genomgå en rehabiliteringsperiod

\footnotetext{
${ }^{11}$ Kommissionerna bestod av 12 medlemmar var. Den ena tillsattes av premiärministern och bestod av regeringens ministrar samt representanter från centrala valkommissionen, polismyndigheten och medlemmar av olika NGOs så som Transparency International Anticorruption Center m.fl. (se News.am 2018). Den andra kommissionen tillsattes av parlamentet och bestod av tre representanter för de fyra olika fraktionerna i parlamentet (se National Assembly 2018).
} 
och spara krafterna till parlamentsvalet som enligt planen skulle hållas våren 2019 (Armenpress 2018b) för att åtminstone behålla sin plats där.

Borgmästarvalet hölls den 23 september och blev en tydlig seger för Pashinyans kandidat som erhöll närmare 81 procent av rösterna (RFERL 2018b). Även om RPA inte hade någon kandidat var utgången ett tydligt och illavarslande omen om vad ett parlamentsval i det rådande opinionsläget kunde resultera i för dem. RPA var dock långt ifrån ensam om denna oro då även andra partier, bland annat ARF som nu ingick i Pashinyans regeringskoalition, gjorde ett katastrofval (mindre än 1 procent av rösterna gick till deras kandidat). Ett liknande resultat i parlamentsvalet för dessa mindre partier skulle innebära att de inte klarade spärren.

När Pashinyan, tydligt uppmuntrad av borgmästarvalets resultat, plötsligt kungjorde att nyval skulle utlysas redan i början av december 2018 så uppstod panik bland alla andra partier, inklusive Pashinyans egna allierade. I en hastigt framtagen motion, som röstades igenom den 2 oktober 2018, gick RPA ihop med Pashinyans regeringsallierade ARF och BHK för att stoppa utlysningen av nyval (RFERL 2018c). Pashinyan kallade motionen för »kontrarevolutionär» och svarade med att sparka de ministrar som tillhörde ARF och BHK. Framtiden får utvisa vad utgången av dessa politiska maktkamper blir. Så länge processen tar sig uttryck i politisk dialog anser många att utvecklingen i sig är ett stort steg i rätt riktning. För första gången i Armeniens moderna historia pågår en livlig, men framförallt sansad politisk kamp där folket har en konkret röst, om än mer på gatorna än i parlamentet genom sina valda ledamöter. Förhoppningen är att ett stabilare politiskt landskap ska göra liknande folkliga mobiliseringar för att tvinga makthavare att rätta sig i leden överflödiga och processen istället flyttar helt in i parlamentet.

\section{Framtiden och utsikter för Armeniens nya riktning}

Situationen som uppkommit i Armenien har utan tvekan gett upphov till ett ypperligt tillfälle att för första gången sedan självständigheten 1991 förbättra landets demokratiska institutioner. $\mathrm{Nu}$ finns möjlighet att genomföra en reell reformering som folket känner att de är konkret delaktiga i. Arbetet lär inte bli lätt och det finns flera fallgropar på vägen. En uppenbar fara är relationen mellan folkets förväntningar och deras tålamod. Förväntningar på snabba resultat riskerar att leda till förlorat förtroende för den nya administrationen, om denna inte kan leverera tillräckligt mycket $i$ en snabb takt. Det kan i sin tur tvinga Pashinyans administration att skynda fram förändringar i en alltför snabb takt och på så sätt orsaka en rekyl hos den gamla eliten, som trots allt fortfarande har omfattande politiskt och ekonomiskt inflytande. Frågan aktualiserades när Pashinyans administration, strax efter maktövertagandet i maj 2018, lanserade det dittills största antikorruptionsprogrammet i Armeniens moderna historia vilket nådde ända upp till Sargsyans inre krets (RFERL 2018a; se även Eurasianet.org 2018). Flera högt uppsatta personer greps och åtalades för korruption, olagligt berikande och stöld av allmänt kapital (Reuters 2018b). 
Den 25 juni, det vill säga knappt två månader efter maktövertagandet, hade redan nära 18 miljarder AMD (cirka 332 miljoner SEK) beslagtagits och återförts till statskassan (Arka News Agency 2018a). Åtgärderna stannade inte enbart inom den ekonomiska sfären utan nådde snart även politiska fall. Det fall som i särklass skapade störst rubriker både i Armenien och internationellt var åklagarämbetets utfärdande av en arresteringsorder för den före detta presidenten Robert Kotjarian som anklagades för att ha brutit mot konstitutionen i anslutning till oroligheterna den 1 mars 2008 då Sargsyan valdes till president (Armenpress 2018a).

Det bör noteras att Pashinyan var den "oppositionella nykomling» som ledde protesterna under mars 2008. Strax efter att oroligheterna hade ägt rum gick han under jorden men valde att överlämna sig till myndigheterna den 1 juli 2009 efter att regeringen hade utfärdat en amnesti (Hetq 2009). Trots detta ställdes han inför rätta och åtalades för uppvigling och våld mot tjänsteman. Han dömdes till fängelse i mars 2010 men släpptes 2011 (Hetq 2011). Året därpå kandiderade han till parlamentet och lyckades bli invald. Det är mot denna bakgrund som arresteringsordern för Kotjarian fick bred kritik från en rad partier och framträdande personligheter, främst från RPA, som varnade för att den här typen av åtgärder var en vendetta mot tidigare ledare och till och med kunde "vara farliga för staten" (Armedia 2018; se även $A$ zatutyun 2018). Vissa kritiker ansåg att dessa handlingar riskerade flytta fokus från reformarbetet och demokratiseringen av landet till bestraffning av föregående makthavare. Armeniens första premiärminister, Vazgen Manukyan, varnade för att "Armenien har blivit en one-man show» och att tveksamma arresteringar av den här typen kan "leda till en liknande situationen som den Armenien uthärdade under 1937, med olagliga arresteringar, krig och isolering från omvärlden» (Mediamax 2018).

Den inhemska processen är dock till en hög grad beroende från yttre faktorer, främst med avseende på hur Ryssland och Azerbajdzjan kan påverka den. Först och främst handlar detta om hur Ryssland väljer att förhålla sig till utvecklingen. Att den ryska faktorn ses som en självklar del i ekvationen blev tydligt i flera artiklar som fokuserade just på varför Ryssland hållit en förhållandevis låg profil gentemot händelseutvecklingen i Armenien (se Way 2018; Riegg 2018). Samtidigt är Karabachkonflikten, som brukligt, också allestädes närvarande i prognoser och spekulationer, både som del av Moskvas trumfkort gentemot Jerevan, men också som en varningslampa för hur ytterligare destabilisering av inrikespolitiken kan utnyttjas av Azerbajdzjan.

I ett optimistiskt scenario får demokratiarbetet och kampen mot korruption fortgå utan större störningar. Om så blir fallet verkar Armenien ha möjlighet att ta viktiga poäng på flera olika planhalvor. Förutom de uppenbara fördelarna med ett öppnare och mer demokratiskt och stabilt samhälle så kan förändringarna också återspeglas i utrikespolitiken och landets internationella profil. Armeniens anseende internationellt, likväl som på hemmaplan, bygger till stor del på så kallad »lågpolitik» (low politics). Eftersom »högpolitiska» resurser baseras på ekonomiska faktorer (t.ex. 
olje- och gasresurser i Azerbajdzjans fall) eller militär signifikans (t.ex. iTurkiets fall), något som dagens Armenien saknar, så får landet förlita sig på lågpolitiska medel så som mänskliga rättigheter, demokrati med mera (Derghoukasian 2012: 248). I detta hänseende kan allmänna val med fördel användas både som illustration och ett lackmustest för utveckling som stärker den lågpolitiska profilen. Det är möjligtvis just av denna anledning som valdagen i Armenien traditionellt kommit att ses som en magisk dag där allt i tillvaron ska vändas till det bättre. Fram tills nu har emellertid valdagar kommit och gått utan att status quo förändrats väsentligt. ${ }^{12}$ Det som behövts har snarare varit en genomgående attitydändring i samhället, något som regler och lagar eller teknologiska lösningar inte kan leverera.

När man ändrade valreglerna 2016 och införde explicita lagar som förbjöd röstfiske och annat fusk så bidrog EU med sju miljoner euro till anskaffandet av tekniska lösningar som skulle hjälpa valprocessen och motarbeta oegentligheter. Fyra miljoner euro skulle användas till teknologiska medel för väljaridentifiering (fingeravtryckläsare m.m.). Två miljoner skulle spenderas på att installera videokameror i vallokalerna för att kunna bevaka dessa under valdagen i realtid (Civilnet 2017). Som sociologen Armine Ishkanian påpekar så sker dock inte allt fusk på valdagen och inne i vallokalen. Fusket sker utanför lokalerna och under dagarna innan när väljarna antingen accepterar betalning för att rösta på ett visst sätt eller blir "uppmanade» på arbetsplatsen att rösta "rätt» för att kunna behålla jobbet (Ishkanian 2017b). Det är snarare civilsamhällets grundsyn på demokrati och ens egna rättigheter och skyldigheter som behöver ändras. Förhoppningen är att "sammetsrevolutionen» har triggat en sådan utveckling i Armenien.

Ett annat försök till förändring var riktad till armenierna runt om i världen genom initiativet att involvera diasporan i Armeniens politiska liv. Inför valet 2017 uppmanades diasporaarmenier att delta i observationsuppdrag parallellt med de inbjudna internationella observationsmissionerna från EU, OSSE med flera (Justice Armenia 2017). Genom att vara på plats och hjälpa till bevakningen av valet så förväntades diasporaarmenierna träffa demokratiförespråkare i Armenien och på så vis lära sig om det politiska landskapet och strukturerna i landet. Den här typen av initiativ syftar till att skapa mer engagemang i samhället som sedan vid valurnorna skulle kunna leda till en verklig förändring. Robert Kennedy lär ha sagt att "valen påminner oss inte enbart om medborgarnas rättigheter men även om deras skyldigheter i en demokrati» (Justice Department 1962: 2). Det är just dessa skyldigheter som har nonchalerats $i$ armeniers fall där man har antagit en alltför passiv roll och istället hela tiden skyllt ifrån sig genom att peka på makthavarnas korruption och yttre aktörers och fienders illvilja gentemot Armenien. Vanstyre har utan tvekan inte bara underminerat demokratin i Armenien utan det har även försvagat landets ställning politiskt och ekonomiskt internationellt och därmed banat väg för yttre

${ }^{12}$ För en analys av valprocessen och demokratisering i Armenien se Sahakyan \& Atanesyan (2006). 


\section{påtryckningar. Förhoppningen är att denna "sammetsrevolution» ska bemyndiga mer ansvarstagande hos Armeniens medborgare och deras aktiva deltagande i landets demokratisering.}

\section{Referenser}

Alijev Ilham (2011) "Karabakh's independence will never be subject of negotiations». News. $a z 13$ juli. Tillgänglig på http://news.az/articles/politics/40321. Läst 14 juni 2018.

Antidze, Margarita \& Hasmik Mkrtchyan (2018) "Acting Armenia leader suggests election as protests roll on». Reuters 25 april. Tillgänglig på reuters.com/article/us-armenia-politics/acting-armenia-leader-suggestselection-as-protests-roll-on-idUSKBN1HW0T6. Läst 12 juli 2018.

Arka News Agency (2018a) "AMD 18 billion returned to government thanks to corruption crackdown in Armenia». 25 juni. Tillgänglig på arka.am/en/news/society/amd_18_billion_returned_to_government_ thanks_to_corruption_crackdown_in_armenia. Läst 5 juli 2018.

Arka News Agency (2018b) "Serzh Sargsyan elected as prime minister». 17 april. Tillgänglig på arka.am/en/ news/politics/serzh_sargsyan_elected_as_prime_minister_/. Läst 18 april 2018.

Armedia (2018) „Kotjariani kalanavorume lurdj hetevankner kunena petutyan hamar». 27 juli. Tillgänglig på armedia.am/arm/news/63124/qocharyani-kalanavorumy-lurj-hetevanqner-kunena-petutyan-hamar. html. Läst 28 juli 2018.

Armeniska riksförbundet i Sverige (2008) "Open letter to the Government of Armenia». Stockholm, 12 mars.

Armenpress (2018a) "2nd President of Armenia Robert Kocharyan remanded into custody by Yerevan court". 28 juli. Tillgänglig på armenpress.am/eng/news/942062.html. Läst 28 juli 2018.

Armenpress (2018b) "First deputy PM announces Armenia's plan to hold snap elections before April at meeting with US Congressman». 20 juli. Tillgänglig på armenpress.am/eng/news/941336. Läst 20 juli 2018.

Asbarez (2018) "Artsakh Defense Ministry releases new footage of Azeri troop buildup». 23 april. Tillgänglig på asbarez.com/171864/artsakh-defense-ministry-releases-new-footage-of-azeri-troop-buildup. Läst 23 april 2018.

Astourian, Stephan H. (2005) "State, homeland, and diaspora: The Armenian and Azerbaijani cases» i Touraj Atabaki \& Sanjyot Mehendale (red.) Central Asia and the Caucasus: Transnationalism and Diaspora. London: Routledge.

Avedian,Vahagn (2017) "The 2017 parliamentary elections in Armenia: In the light of the new constitution». Baltic Worlds. 7 april. Tillgänglig på balticworlds.com/the-2017-parliamentary-elections-in-armenia/?s=armenia. Läst 4 juni 2018.

Avedian, Vahagn (2013) "The unsustainable European policy towards the South Caucasus». Foreign Policy fournal. 13 oktober 2013. Tillgänglig på foreignpolicyjournal.com/2013/10/31/the-unsustainableeuropean-policy-towards-the-south-caucasus/view-all. Läst 29 september 2018.

Azatutyun (2013a) »European leader rejects Armenian opposition criticism». 15 mars. Tillgänglig på azatutyun. am/a/24930070.html. Läst 17 juni 2018.

Azatutyun (2013b) "Armenia-EU accord 'off table'». 10 september. Tillgänglig på azatutyun.am/a/25100726. html. Läst 26 november 2018.

Azatutyun (2017) "Armenian ruling party again accused of vote buying». 12 maj. Tillgänglig på azatutyun. am/a/28482569.html. Läst 17 juli 2018 .

Azatutyun (2018) "Republicans, Dashnaks slam charges against Kocharian». 27 juli. Tillgänglig på azatutyun. am/a/29394028.html. Läst 28 juli 2018.

BBC (2008) "Eight killed in Armenia protests». 2 mars. Tillgänglig på news.bbc.co.uk/2/hi/europe/7273497. stm. Läst 15 juni 2018.

$B B C$ (2015) "Armenia fraud claims mar referendum on constitution». 7 december. Tillgänglig på https://www. bbc.com/news/world-europe-35025853. Läst 7 juni 2018.

$B B C$ (2018) "Armenia crisis: Opposition leader Pashinyan fails in bid to be PM». 1 maj. Tillgänglig på bbc. com/news/world-europe-43958196. Läst 1 maj 2018.

Berberian,Viken (2018) "Democracy is held back in Armenia». The NerwYork Times 2 maj. Tillgänglig på nytimes. com/2018/05/02/opinion/armenia-nikol-pashinyan.html. Läst 1 juli 2018.

Civilnet (2017) "EU Invests unprecedented funds in Armenia's upcoming election». 18 mars. Tillgänglig på civilnet. am/news/2017/03/18/EU-Invests-unprecedented-funds-in-Armenia's-upcoming-election/310930. Läst 8 juli 2018. 
Civilnet (2018) "Yerevan mayor Taron Margaryan resigns, 9 juli. Tillgänglig på civilnet.am/news/2018/07/09/ Yerevan-Mayor-Taron-Margaryan-Resigns/341036. Läst 8 juli 2018.

Defeis, Elizabeth F. (1998) "Elections and democracy: Armenia, a case study». Digital Commons at Loyola Marymount University and Loyola Law School. 20 Loy. L.A. Int'l \& Comp. L.J. 455. Tillgänglig på http:// digitalcommons.lmu.edu/cgi/viewcontent.cgi?article=1444\&context=ilr. Läst 22 juni 2018.

Derghoukasian, Khatchik (2012) "The Armenian Genocide on the international agenda: The case for diplomatic engagement». Haigazian Armenological Review 32: 229-260.

Eurasianet.org (2018) "Armenia’s revolutionary government steps up anti-corruption purge». 19 juni. Tillgänglig på eurasianet.org/s/armenias-revolutionary-government-steps-up-anti-corruption-purge. Läst 25 juli 2018.

European Commission (2013) "EU-Armenia deep and comprehensive free trade area». 24 juli. Tillgänglig på trade.ec.europa.eu/doclib/press/index.cfm?id=952. Läst 1 juli 2018.

Europeiska Parlamentet (2015) "Europaparlamentets resolution 10 september 2015 om Azerbajdzjan (2015/2840(RSP))». 10 september. Tillgänglig på europarl.europa.eu/sides/getDoc.do?pubRef=-//EP// TEXT+TA+P8-TA-2015-0316+0+DOC+XML+V0//SV. Läst 15 juni 2018.

Ferris-Rotman, Amie (2018) "Did Armenia just dance its way to revolution?». Washington Post 3 maj. Tillgänglig på washingtonpost.com/news/worldviews/wp/2018/05/03/did-armenia-just-dance-its-way-torevolution/?noredirect $=$ on\&utm_term $=.7 \mathrm{~b} 1771125349$. Läst 3 maj 2018.

Füle, Štefan (2013) "Statement on the pressure exercised by Russia on countries of the Eastern Partnership". European Commission 11 september. Tillgänglig på europa.eu/rapid/press-release_SPEECH-13-687_ en.htm. Läst 26 november 2018.

Gogia, Giorgi (2017) "EU red carpet for Azerbaijan sends wrong message». EUobserver 6 febrauri. Tillgänglig på euobserver.com/opinion/136802. Läst 15 juni 2018.

Grijalva, Daniela Paredes (2017) "Caring for the homeland from a distance: The Armenian diaspora in Vienna and transnational engagements» i Gabriele Rasuly-Paleczek \& Maria Six-Hohenbalken (red.) Migration and its Impact on Armenia. A Field Practice. Vienna: University of Vienna. Tillgänglig på univie.ac.at/ alumni.ksa/wp-content/uploads/ASSA-SN-2017-01_Migration-and-its-impact-on-Armenia.pdf. Läst 15 oktober 2018.

Hetq (2009) "Nikol Pashinyan turns himself in». 1 juli. Tillgänglig på hetq.am/eng/news/37902/nikol-pashinyanturns-himself-in.html. Läst 3 december 2018.

Hetq (2011) "Nikol Pashinyan released from prison». 27 maj. Tillgänglig på hetq.am/eng/news/1639/nikolpashinyan-released-from-prison.html. Läst 28 juli 2018.

Hraparak (2018) "Miyan nra hamar, vor yerkrum yeghav heghapokhutyun, ho martkants ugheghum el cheghav heghapokhutyun?». 6 juli. Tillgänglig på hraparak.am/posts/5b3f0a0f61327406b4d9edf4. Läst 10 juli 2018.

Ibrahim, Enes (2011) "Armenia's aggressive policies main obstacle for country's development». News.az 31 oktober. Tillgänglig på http://news.az/articles/politics/47854. Läst 14 juni 2018.

Ishkanian, Armine (2017a) "Armenia's election: The status quo wins at the expense of democracy». EUROPP European Politics and Policy. LSE 4 april. Tillgänglig på blogs.lse.ac.uk/europpblog/2017/04/04/armeniaselection-the-status-quo-wins-at-the-expense-of-democracy. Läst 10 juli 2018.

Ishkanian, Armine (2017b) "Review of Anna Zhamakochyan, Zhanna Andreasyan, Sona Manusyan, and

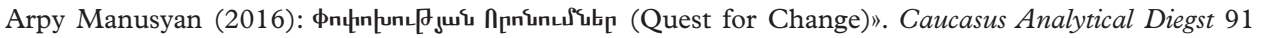
(7 februar): 11-13. Tillgänglig på css.ethz.ch/content/dam/ethz/special-interest/gess/cis/center-forsecurities-studies/pdfs/CAD91.pdf. Läst 22 juni 2018.

Justice Armenia (2017) "2017 Transparency tour. Help advance democracy in Armenia as an electoral observer». Tillgänglig på justicearmenia.org/2017-transparency-tour.html. Läst 27 juli 2018.

Justice Department (1962) "Address of Attorney General Robert F. Kennedy». oktober 6. Tillgänglig på justice. gov/sites/default/files/ag/legacy/2011/01/20/10-06-1962.pdf. Läst 20 juni 2018.

Libaridian, Gerard J. (1991) Armenia at the Crossroads: Democracy and Nationhood in the Post-Soviet Era. Essays, Interviews, and Speeches by the Leaders of the National Democratic Movement in Armenia. Watertown: Blue Crane Books.

Libaridian, Gerard J. (2004) Modern Armenia: People, Nation, State. New Brunswick: Transaction Publishers.

Linde, Fabian (2015) "Ekonomisk modernisering eller stormaktspolitik?». Utrikesmagasinet 10 februari. Tillgänglig på utrikesmagasinet.se/analyser/2015/februari/ekonomisk-modernisering-eller-stormaktspolitik. Läst 1 juli 2018.

Lragir (2018)»HHKn mnats hakaheghapokhutyan kokordin». 25 juli.Tillgänglig på lragir.am/2018/07/25/367058. Läst 25 juli 2018. 
Mammadov, Galib (2011) "Nagorno Karabakh conflict: Armenia's victory or nightmare?». Foreign Policy fournal 13 oktober. Tillgänglig på http://www.foreignpolicyjournal.com/2011/10/13/nagorno-karabakhconflict-armeniasvictory-or-nightmare-2. Läst 14 juni 2018.

Mediamax (2018) "Armenia's first PM: The country has become a one-man show». 30 juli. Tillgänglig på mediamax.am/en/news/politics/29609. Läst 31 juli 2018.

Mirzoyan, Alla (2010) Armenia, the Regional Powers, and the West: Between History and Geopolitics. New York: Palgrave Macmillan.

National Assembly of the Republic of Armenia (1999) Electoral Code of the Republic of Armenia. 5 februari. Tillgänglig på parliament.am/legislation.php?sel=show\&ID=2020\&lang=eng. Läst 3 juli 2018.

National Assembly of the Republic of Armenia (2015) Amendments to the Constitution of the Republic of Armenia. 6 december. Tillgänglig på parliament.am/parliament.php?id=constitution\&lang=eng\#7. Läst 4 juni 2018.

National Assembly of the Republic of Armenia (2018) Foint Statement of RA National Assembly Factions. 20 juni. Tillgänglig på parliament.am/news.php?cat_id=2\&NewsID $=10447 \& y e a r=2018 \&$ month $=06 \&$ day $=20 \&$ lang=eng. Läst 21 juni 2018.

News.am (2015) "Heritage: Armenia constitutional reform is implemented to establish party-state». 4 september. Tillgänglig på news.am/eng/news/284599.html. Läst 4 juni 2018.

News.am (2018) "Pashinyann entrakan orensdrutyan barepokhumneri veraberyal voroshum e storagrel; handznazhoghov e steghtzum». 20 juni. Tillgänglig på news.am/arm/news/457681.html. Läst 21 juni 2018.

OSSE/ODIHR (2016) Armenia, foint Opinion on the Draft Electoral Code. Venice Commission Opinion No. 835/2016 6 juni. Tillgänglig på venice.coe.int/webforms/documents/default.aspx?pdffile=CDL-AD(2016)019-e. Läst 8 juni 2018.

PACE (2017) "Armenian elections well administered, but process tainted by credible information of vote-buying». 3 april. Tillgänglig på assembly.coe.int/nw/xml/News/News-View-EN.asp?newsid=6581\&lang=2. Läst 17 juli 2018.

Riegg, Stephen (2018) "Why Russia won't interfere in Armenia's velvet revolution", RealClear World 8 maj. Tillgänglig på realclearworld.com/articles/2018/05/08/why_russia_wont_interfere_in_armenias_velvet_ revolution_112792.html. Läst 25 oktober 2018.

RFERL (2018a) "Armenia charges ex-president’s brother in financial crime probe». 7 Juli. Tillgänglig på rferl. org/a/pashinian-says-armenian-law-enforcement-not-targeting-sarkisian-corruption-denies-politicalprosecution/29348230.html. Läst 9 juli 2018.

RFERL (2018b) "Armenian PM Pashinian's bloc takes landslide election victory in Yerevan». 24 september. Tillgänglig på https://www.rferl.org/a/armenian-yerevan-municipal-election-pashinian-bloc-massivelead/29505443.html. Läst 30 september 2018.

RFERL (2018c) "Tens of thousands protest outside Armenian Parliament against 'counterrevolutionary' bill». 2 oktober. Tillgänglig på https://www.rferl.org/a/pashinian-supporters-protest-outside-armenianparliament-against-counterrevolutionary-bill/29521911.html. Läst 3 oktober 2018.

Reuters (2018a) "Armenian parliament elects Pashinyan as prime minister». 8 maj. Tillgänglig på https://www. reuters.com/article/us-armenia-politics-pashinyan/armenian-parliament-elects-pashinyan-as-primeminister-idUSKBN1I911D. Läst 8 maj 2018.

Reuters (2018b) "Armenia arrests former influential official». 19 juni. Tillgänglig på reuters.com/article/usarmenia-arrests/armenia-arrests-former-influential-official-idUSKBN1JF2RV. Läst 21 juni 2018.

Sahakyan, Vahe \& Arthur Atanesyan (2006) "Democratization in Armenia: Some trends of political culture and behavior». Demokratizatsiya: The fournal of Post-Soviet Democratization 14 (3): 347-354.

Tert.am (2018) "Republican Party of Armenia nominates Serzh Sargsyan for prime minister!». 14 april. Tillgänglig på tert.am/en/news/2018/04/14/serzh-sargsyan/2662969. Läst 14 april 2018.

The Economist (2016) »Nagorno-Karabakh's war: A frozen conflict explodes». 9 april. Tillgänglig på economist. com/europe/2016/04/09/a-frozen-conflict-explodes. Läst 18 juni 2018.

The Guardian (2018) „Shock as Armenia's prime minister steps down after 11 days of protests». 23 april. Tillgänglig på theguardian.com/world/2018/apr/23/serzh-sargsyan-resigns-as-armenias-prime-ministerafter-protests. Läst 23 april 2018.

Transparency International (2018) "Entrakan orensgrki barepokhumneri handznazhoghovi yerkrord niste». 28 juni, Jerevan. Tillgänglig på transparency.am/hy/news/view/2408. Läst 5 juli 2018.

de Waal, Thomas (2018) Sometimes Armenian protests are just Armenian protests. Carnegie Europe 23 april. Tillgänglig på carnegieeurope.eu/2018/04/23/sometimes-armenian-protests-are-just-armenian-protestspub-76161. Läst 20 oktober 2018. 


\section{2 | VAHAGN AVEDIAN}

Way, Lucan Ahmad (2018) "Why didn't Putin interfere in Armenia's Velvet Revolution?». Foreign Affairs17 maj. Tillgänglig på https://www.foreignaffairs.com/articles/armenia/2018-05-17/why-didnt-putin-interferearmenias-velvet-revolution. Läst 25 oktober 2018.

Welt, Cory (2012) Briefing on 'Democratization in the Caucasus: Elections in Armenia, Azerbaijan, and Georgia'. Commission on Security and Cooperation in Europe (U.S. Helsinki Commission) 23 maj. Tillgänglig på cdn.americanprogress.org/wp-content/uploads/issues/2012/05/pdf/welt_testimony.pdf. Läst 28 juli 2018. 